\title{
SENTRALISASI PENGAWASAN INFORMASI JARINGAN MENGGUNAKAN BLOCKCHAIN ETHEREUM
}

\author{
Muhammad Fajar Sidiq ${ }^{1}$, Akbari Indra Basuki*2, Halim Firdaus ${ }^{3}$, Muhammad Aldi Baihaqi ${ }^{4}$ \\ ${ }^{1}$ Fakultas Teknologi Industri dan Informatika, Institut Teknologi Telkom Purwokerto \\ ${ }^{2}$ Pusat Penelitian Informatika, Lembaga Ilmu Pengetahuan Indonesia \\ ${ }^{3,4}$ Fakultas Teknik Telekomunikasi dan Elektro, Institut Teknologi Telkom Purwokerto \\ Email: 1'ajar@ittelkom-pwt.ac.id, ${ }^{2}$ akbari@informatika.lipi.go.id, ${ }^{3} 16101094 @$ ittelkom-pwt.ac.id, \\ ${ }^{4} 16101100 @$ ittelkom-pwt.ac.id \\ *Penulis Korespondensi
}

(Naskah masuk: 04 November 2019, diterima untuk diterbitkan: 26 November 2020)

\begin{abstract}
Abstrak
Pengawasan jaringan pada beberapa kantor yang berlokasi berjauhan sangat sulit dilakukan kerana keterbatasan tenaga ahli, biaya, dan teknologi pendukung. Penelitian yang sudah ada tidak dapat menyediakan sistem pengawasan jaringan yang mampu menjamin tiga aspek keamanan sekaligus, yaitu: availability, integrity, dan confidentiality. Teknologi blockchain mampu menyediakan sistem pengawasan jaringan secara terpusat dan aman dengan menjamin keamanan sistem komunikasi pelaporan dan sistem basis data pelaporan. Penelitian ini bertujuan untuk menyajikan purwarupa sistem pengawasan konfigurasi dan statistik jaringan menggunakan jejaring blockchain Ethereum. Metode pengawasan mengharuskan program controller pada setiap jaringan kantor cabang untuk secara berkala menarik informasi flow-rules dari setiap perangkat jaringan dan melaporkan data tersebut dalam sebuah transaksi ke jejaring blockchain. Pada penelitian ini dianalisa dua jenis skema pengiriman transaksi: transaksi berbasis smart contract dan transaksi berbasis zero-payment. Berdasarkan hasil pengujian, transaksi berbasis zero-payment secara rerata hanya membutuhkan sekitar $6 \%$ dari biaya transaksi smart contract. Perkiraan biaya bulanan untuk pensamplingan informasi setiap 10 menit adalah sekitar 1,19 ether per-perangkat jaringan. Meskipun demikian, metode pada penelitian ini lebih sesuai untuk diterapkan pada jejaring Ethereum jenis Proof-of-Authority (PoA) dibandingkan jenis Proof-of-Work (PoW) karena harga Ether yang mahal.
\end{abstract}

Kata kunci: Sentralisasi, Pengawasan, Jaringan, Blockchain, Ethereum

\section{CENTRALIZED MONITORING OF NETWORK INFORMATION USING ETHEREUM BLOCKCHAIN}

\begin{abstract}
Centralized monitoring of remote networks is hard to implement due to the high cost, lack of experts, and the missing key technologies. The existing researches are unable to provide a secure, centralized monitoring system that satisfies three security aspects, namely: availability, integrity, and confidentiality. Blockchain technology meets those three requirements by providing a reliable reporting and immutable database system. In this paper, we proposed a prototype of a centralized monitoring system that records network statistics and configurations into the blockchain ledger. The method requires the network controller to periodically fetch network information from every network device and submit it as a single blockchain transaction. We compare two kinds of transaction schema, smart-contract based and zero-payment based reporting schemes. The evaluations show that zero-payment transactions only cost $6 \%$ of the smart-contract transactions. The estimation of the monthly cost is 1.19 ether per-device for 10-minutes data sampling. Nevertheless, the proposed method is applicable only for the Proof-of-Authority (PoA) Ethereum networks. It is not feasible for the Ethereum main network that uses Proof-of-Work (PoW) due to the high cost of Ether.
\end{abstract}

Keywords: Centralized, Network, Monitoring, Blockchain, Ethereum

\section{PENDAHULUAN}

Pada kasus perusahaan memiliki banyak kantor cabang yang tersebar di berbagai lokasi, potensi serangan terhadap sistem jaringan dapat berasal dari berbagai arah, baik dari dalam maupun dari luar. Potensi serangan dari luar dapat diminimalkan dengan menggunakan firewall untuk memilah paket 
(Fiessler dkk, 2018) (Phatak dkk, 2018), dan virtual private network (VPN) sebagai sistem komunikasi antar kantor (van der Pol dkk, 2016) (Patil dkk, 2018) (Subratie dkk, 2019). Di sisi lain, potensi serangan dari dalam sangat sulit dideteksi karena celah keamanan yang beragam. Celah keamanan dapat berasal dari program penyusup seperti jenis trojan dan malware ataupun karena kesalahan konfigurasi jaringan di kantor cabang yang diekploitasi oleh penyerang.

Pada umumnya pihak penyerang lebih memilih untuk menyerang kantor cabang karena minimnya pengawasan dari kantor pusat dan terbatasnya jumlah tenaga ahli jaringan. Penggunaan protokol VPN yang dari awal bertujuan untuk menangkal serangan dari luar dapat dieksploitasi oleh penyusup untuk mengakses seluruh jaringan perusahaan.

Untuk mencegah potensi serangan dari dalam, beberapa penelitian sebelumnya lebih berfokus pada penggunaan sistem autentifikasi pengguna seperti proxy server dan firewall (Germann dkk, 2018). Sistem pengamanan berbasis proxy server sangat mudah diretas. Apabila penyerang dapat memperoleh informasi username dan password dari komputer pegawai, maka penyusup dapat mengakses jaringan tanpa terdeteksi.

Di sisi lain, penggunaan firewall dapat meningkatkan keamanan jaringan dengan membatasi masuknya perangkat baru yang tidak terdaftar. Meskipun pihak penyerang dapat memperoleh akses yang sah/valid, identitas MAC adress dari perangkat penyerang dapat dideteksi oleh firewall. Meskipun demikian, pihak penyerang dapat mamalsukan informasi MAC address (MAC address spoofing) untuk menyamarkan perangkatnya dan masuk ke jaringan tanpa terdeteksi. Jenis serangan ini hanya dapat terdeteksi apabila pihak pengelola jaringan melakukan pengawasan menyeluruh terhadap informasi trafik dan statistik jaringan.

Dengan demikian, metode yang paling akurat untuk menangkal berbagai jenis serangan adalah dengan melakukan pengawasan jaringan secara menyeluruh. Pengelola jaringan pusat harus dapat menganalisa setiap statistik dan konfigurasi jaringan di seluruh kantor cabang. Pada jaringan Software Defined Networking (SDN), tugas utama program controller adalah untuk memprogram dan memantau kondisi jaringan. Skema pengawasan terpusat dapat direalisasikan dengan cara memerintahkan program controller di setiap kantor cabang untuk mengirimkan data statistik dan konfigurasi jaringan ke pengelola pusat.

Masalah utama pada sistem pengawasan terpusat adalah tentang bagaimana cara menjamin keamanan sistem, baik dari segi komunikasi pelaporan dan sistem penyimpanan data laporan. Berangkat dari masalah tersebut, diperlukan sistem pengawasan jaringan yang terpusat yang mampu menjamin tiga aspek keamanan sebagai berikut:

1. Ketersediaan data pelaporan (availability)
2. Integritas data pelaporan (integrity)

3. Kerahasiaan data pelaporan (confidentiality)

Penelitian ini bertujuan untuk menyajikan purwarupa sistem pengawasan jaringan secara terpusat menggunakan jejaring blockchain Ethereum (Buterin, 2014) sebagai penjamin kemanan untuk sistem komunikasi pelaporan dan sistem basis data pelaporan. Teknologi blockchain dipilih sebagai solusi pada penilitian ini karena mampu menjawab tiga syarat kemanan yang diperlukan, yaitu: confidentiality, integrity, dan availability.

Pada penelitian ini, bab 2 menyajikan metode penelitian yang berisi tentang persyaratan keamanann sistem, pemilihan teknologi blockchain yang sesuai, dan cara pengukuran performa sistem. Selanjutnya, bab 3 membahas perancangan dan implementasi sistem. Bab 4 menampilkan perhitungan skalabilitas sistem pencatatan berbasis analisa biaya pencatatan. Bab 5 memaparkan diskusi tentang peningkatan efisiensi biaya pencatatan dan perbandingan ketersediaan data. Terakhir, bab 6 menyajikan kesimpulan.

\section{METODE PENELITIAN}

\subsection{Persyaratan kemanan sistem}

Persyaratan kemanan sistem secara umum terdiri dari tiga komponen, yaitu: Kerahasiaan (confidentiallity), Integritas (integrity), dan ketersediaan sistem (availability).

Informasi statistik dan konfigurasi jaringan merupakan data sensitif dan krusial bagi sebuah perusahaan. Pengiriman data ke kantor pusat melalui internet sangat rentan akan pencurian data. Sistem pelaporan informasi jaringan harus mampu menjamin confidentiallity dari data yang dilaporkan. Cara paling lazim untuk menjaga aspek kerahasiaan data dan mencegah adanya pencurian data atau akses tidak sah adalah dengan cara mengenkripsi enkripsi.

Pengiriman melalui internet membuka celah bagi penyerang untuk memalsukan informasi jaringan. Sistem pelaporan yang aman harus dapat memvalidasi informasi jaringan mana saja yang secara otentik dihasilkan oleh program controller dan mana yang tidak.

Ketersediaan sistem untuk selalu siap memberikan informasi ke pengguna merupakan aspek yang paling sulit untuk dijamin. Perusahaan besar seperti Google, Facebook, dan lainya terkadang gagal menjaga ketersediaan server akibat serangan Distributed Denial-of-Services (DDoS). Sistem penyimpanan informasi jaringan harus tahan terhadap serangan jenis DDoS sehingga dapat memberikan informasi jaringan kapan saja ketika dibutuhkan. Alasan utama adalah karena jaringan merupakan suatu sistem dinamis yang mana serangan dapat terjadi kapan saja. Maka dari itu, sistem pengawasan jaringan harus tersedia setiap saat dan selalu melaporkan informasi jaringan secara periodik. 


\subsection{Pemilihan teknologi blockchain}

Blockhcain bekerja secara terdistribusi, yang mana setiap node/komputer terhubung satu sama lain secara langsung atau peer-to-peer. Dengan skema terdistribusi, pihak penyerang tidak akan mampu untuk menghapus data jaringan yang dilaporkan karena data tersebut turut pula disimpan keseluruh node/komputer yang terhubung ke jejaring blockchain. Untuk menghapus data pelaporan, maka pihak penyerang harus menghapus seluruh salinan data yang tersimpan di berbagai belahan dunia yang mana sangat mustahil untuk dilakukan. Oleh karena itu, data jaringan yang dilaporkan melalui jejaring blockchain akan tetap terjaga ketersediannya karena dapat diperoleh dari berbagai sumber. Dengan demikian, jejaring blockchain telah memenuhi syarat availability.

Jejaring blockchain memvalidasi keabsahan suatu transaksi dengan cara merujuk pada nilai signature dari transaksi. Selama pihak penyerang tidak mengetahi kunci private program controller, maka mereka tidak akan dapat memalsukan informasi jaringan karena tidak dapat menghasilkan nilai signature yang sah. Dengan demikian, teknologi blockchain mampu menjamin nilai integritas (integrity) data yang dilaporkan.

Jejaring blockchain bersifat terbuka, yang mana siapa saja dapat membaca data yang terekam untuk menjamin akuntabilitas jejaring blockchain. Untuk menjaga kerahasiaan data yang dilaporkan, maka pada penelitian ini, program controller akan selalu mengenkripsi data yang dilaporkan. Dengan data yang terenkripsi, maka sistem pelaporan berbasis blockchain mampu memenuhi aspek confidentiallity.

Jejaring blockchain terdiri dari berbagai jenis dan varian. Berdasarkan partisipasi pengguna dan metode pembuatan blok baru, jaringan blockchain terdiri dari tiga jenis yaitu: permissionless (Buterin, 2014), permission-based (Helebrandt, P. dkk, 2018) (Koštál, K., 2019) dan private (Mendez Mena, D. M. dkk, 2018). Blockchain jenis permissionless mengizinkan semua orang untuk bergabung baik dalam mencatatkan transaksi atau dalam berlombalomba dalam membuat blok baru dengan cara memecahkan tingkat kesulitan terkini. Blokchain jenis permission-based dan private memiliki kesamaan dalam hal partisipasi pengguna yang bersifat terbatas. Perbedaan keduanya terletak pada prosedur pembuatan blok. Blockchain jenis permission-based membuat blok baru berdasarkan konsensus dari pengguna, sedangkan pada jenis private pembutan blok baru ditentukan secara terpusat oleh pengelola blokchain.

Berdasarkan aspek integritas, ketiga jenis blockchain tersebut memilliki tingkat keamanan yang sama karena menggunakan digital signature yang dihasilkan menggunakan kriptografi asimetris.

Berdasarkan aspek kerahasiaan, blokchain jenis permission-based dan private memiliki tingkat kerahasian yang lebih baik dari pada jenis permissionless karena informasi jaringan yang tersimpan di dalam transaksi hanya dapat dibaca oleh kalangan terbatas. Meskipun demikian, hal tersebut tidak menjamin kerahasian data karena pengguna jejaring blockchain yang lain masih dapat membaca informasi jaringan. Untuk menjamin kerahasiaan data secara mutlak, maka ketiga jenis jejaring blockchain tersebut harus menggunakan sistem enkripsi data tambahan.

Berdasarkan aspek ketersediaan (availablity), blockchain jenis permissionless jauh lebih baik daripada blockchain jenis permission-based dan private karena data tersimpan di berbagai belahan dunia. Apabila suatu node blockchain atau koneksi internet di salah satu daerah terputus, maka pengguna masih dapat mengambil data dari node yang berada di daerah atau negara lain.

Penelitian ini menggunakan blockchain jenis permissionless berbasis jejaring Ethereum sebagai mana pada penelitian sebelumnya (El Houda dkk, 2019) (Kamboj, P. dkk, 2019) (Niya, S. R., 2018). Keterbaruan dari sistem yang diajukan adalah adanya penggunaan enkripsi AES untuk menjamin aspek kerahasiaan data yang dilaporkan. Penelitian ini menggunakan blockchain Ethereum karena dua faktor utama. Pertama, jejaring Ethereum menyediakan jaringan pengujian (test network) yang dapat digunakan tanpa harus membayar biaya transaksi. Kedua, jejaring Ethereum memiliki fitur smart contract yang dapat mengotomasikan proses autentifikasi transaksi. Pada penelitian ini, akan diuji coba dua jenis transaksi, yaitu transaksi berbasis smart contract dan transaksi berbasis pembayaran/transfer.

\subsection{Metode pengukuran performa sistem}

Pengujian sistem dilakukan dengan cara mengemulasikan sistem jaringan SDN menggunakan program Mininet (Kaur dkk, 2014). Untuk skenario jaringan multi-lokasi, satu lokasi jaringan diimplementasikan dalam satu buah virtual machine (VM). Setiap jaringan dikendalikan oleh sebuah controller yang terhubung ke jejaring blockchain melalui internet. Controller mencatatkan konfigurasi dan statistik jaringan ke jejaring blockchain setiap rentang waktu tertentu $(\mathrm{t})$.

Analisa skalabilitas dihitung dengan cara menganalisa implikasi dari nilai resolusi pengambilan data (update time / $\mathrm{U}_{\text {time}}$ ) dan besaran data $\left(\mathrm{T}_{\text {size }}\right)$ terhadap biaya pencatatan ke jejaring blockchain (update cost / $\mathrm{U}_{\text {cost }}$ ).

Pada penelitian ini, akan dianalisa dua jenis kasus dan dua jenis skema pelaporan. Kedua kasus tersebut adalah: perangkat jaringan dengan jumlah flow-rules yang rendah (10 aturan), dan jumlah flowrules tinggi (100 aturan). Sedangkan kedua jenis skema pelaporan adalah skema transaksi berbasis smart contract (Buterin, 2014) dan transaksi 
berbasis zero-payment atau pembayaran dengan nilai nol (0).

Aturan dasar mengenai pengiriman transaksi ke jejaring blockchain adalah pengirim harus memastikan bahwa transaksi yang dikirim berhasil tercatatkan pada block terbaru sebelum mengirim transaksi berikutnya. Jika syarat tersebut tidak terpenuhi, maka transaksi sebelumnya boleh jadi tidak akan pernah tercatatkan selamanya atau tercatatkan secara tidak terurut. Untuk memastikan transaksi berhasil tercatatkan dengan baik, waktu pensamplingan dan pencatatan data ke jejaring blockchain $\left(\mathrm{U}_{\text {time }}\right)$ harus lebih besar dari waktu pembuatan blok baru (block creation time / $\mathrm{B}_{\mathrm{CT}}$ ) (persamaan 1).

$U_{\text {time }} \geq B_{C T}$

Hal lain yang perlu diperhatikan adalah adanya pembatasan ukuran transaksi untuk mencegah serangan denial-of-services (DoS) terhadap jejaring blockchain. Maka dari itu, ukuran input data sebuah transaksi tidak boleh melebihi batas kapasitas input data (data size) dan biaya transaksi per-blok (block gas limit).

Besaran informasi jaringan yang akan dicatakan $\left(\mathrm{T}_{\text {size }}\right)$ tergantung pada dua hal, yaitu: jumlah flow-rule yang dipasang pada setiap perangkat $\left(\mathrm{N}_{\mathrm{R}}\right)$, dan frekuensi sampling data $\left(\mathrm{U}_{\text {time }}\right)$. Hubungan antara variabel ditunjukkan oleh persamaan 2. Nilai $F_{i}$ merujuk kepada ukuran flowrule nomor ke-i dalam satuan byte.

$T_{\text {size }}=\sum_{i=1}^{N_{R}} F_{i}$

Semakin besar informasi jaringan yang akan dicatatkan $\left(\mathrm{T}_{\text {size }}\right)$, maka biaya pencatatan dari transaksi $\left(\mathrm{U}_{\text {cost }}\right)$ juga semakin besar. Total biaya pencatatan $\left(\mathrm{U}_{\text {cost }}\right)$ bergantung pada ukuran input data transaksi $\left(\mathrm{T}_{\text {size }}\right)$, nilai gas limit per byte (GLPB), dan gas price (persamaan 3). Nilai GLPB bersifat konstan dan ditentukan oleh kode program blockhcain. Sedangkan nilai gas price pada umumnya ditentukan oleh pengirim dengan nilai minimal 1 Gwei (giga wei, 1 wei = satu per-milyar Ether).

$$
U_{\text {cost }}=T_{\text {size }} * G L P B * \text { gas price }
$$

Hal lain yang perlu diperhatikan adalah nilai gas price menentukan seberapa cepat transaksi akan tercatatkan ke jejaring blockchain. Penambang/miner cenderung untuk terlebih dahulu memilih transaksi-transaksi dengan nilai gas price yang tinggi. Untuk mencegah pencatatan yang tidak terurut, maka nilai gas price harus bersifat konstan.

\section{PERANCANGAN DAN IMPLEMENTASI SISTEM}

Secara umum sistem terbagi kedalam tiga bagian utama sebagaimana ditampilkan pada
Gambar 1. Pada sistem yang kami ajukan, hanya pengelola pusat (Main admin) dan program controller di setiap kantor cabang yang terhubung ke jejaring blockchain. Tiga bagian sistem adalah sebagai berikut:

1. Sistem jaringan SDN,

2. Aplikasi controller pengirim transaksi untuk pencatatan informasi jaringan ke jejaring blockchain,

3. Aplikasi pengawasan pusat.

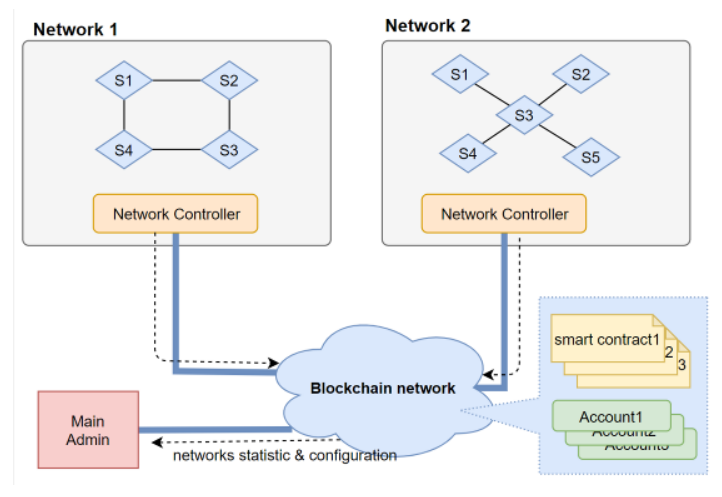

Gambar 1. Skema umum pengawasan jaringan terpusat berbasis blockchain smart conract.

\subsection{Jaringan SDN}

Pada jaringan SDN, sebuah controller jaringan bertugas untuk mengontrol seluruh perilaku perangkat jaringan. Pengelola jaringan dapat memprogram dan memonitor aturan-aturan (flowrules) yang terpasang pada setiap perangkat jaringan menggunakan program controller.

Pada metode yang kami ajukan, untuk menghindari kesalahan konfigurasi perangkat jaringan oleh pengelola jaringan lokal, program controller secara berkala akan mengirimkan informasi mengenai konfigurasi dan statistik jaringan ke pengelola pusat. Program controller di jaringan lokal memiliki tambahan aplikasi berupa perekam konfigurasi dan statistik jaringan yang kemudian melaporkan rekaman tersebut melalui jejaring blockchain.

Pada penelitian ini digunakan protokol OpenFlow (McKeown dkk, 2008) untuk menghubungkan antara program controller dengan perangkat jaringan. Sedangkan jenis jaringan yang digunakan adalah jaringan out-of-band (Gambar 2). Setiap perangkat jaringan terhubung ke controller melalaui sebuah koneksi pengontrol (control channel) terdedikasi. 

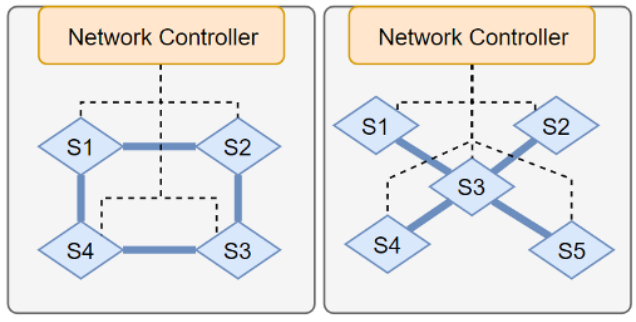

--- control channel kabel jaringan

Gambar 2. Ssitem jaringan out-of-band, seluruh switch terkoneksi langsung ke controller.

Controller jaringan mengambil informasi konfigurasi dan statistik flow-rules dari setiap perangkat jaringan setiap $\mathrm{t}$ detik sekali dan menyimpan data tersebut kedalam database lokal. Sebuah proses anakan (subprocess) bertugas untuk mengirimkan data tersebut ke jejaring blockchain sesuai dengan alamat pengiriman yang telah ditentukan sebelumnya

Pada penelitian ini, digunakan tiga nilai $t$, yaitu: 15 detik, 1 menit, dan 10 menit. Semakin cepat waktu pengambilan sampel, maka semakin besar pula data yang harus dicatatkan ke jejaring blockchain. Meskipun hal ini akan meningkatkan biaya pencatatan $\left(\mathrm{U}_{\text {cost }}\right)$, waktu sampling yang cepat memungkinkan penangkapan perubahan konfigurasi jaringan secara lebih akurat. Sebagai contoh, pihak penyerang dapat merubah pengaturan jaringan dalam waktu singkat untuk kemudian mengembalikannya ke kondisi semula ketika sudah berhasil menyerang target. Apabila waktu sampel lebih besar dari pada waktu perubahan, maka perubahan pada jaringan tersebut tidak dapat terdeteksi oleh pengelola pusat.

Spesifikasi jaringan SDN yang diamati adalah sebagai berikut. Program controller jaringan yang digunakan adalah Ryu (Ryu SDN Framework, 2011) sedangkan perangkat jaringan yang digunakan adalah OpenVSwitch (Pfaff dkk, 2015) dengan protokol OpenFlow versi 1.3.

\subsection{Aplikasi pengirim transaksi}

Aplikasi pengirim transaksi merupakan subprocess dari controller Ryu yang diprogram menggunakan bahasa Nodejs dan pusataka ethers (Ethers.js, 2016). Sedangkan jejaring Ethereum yang digunakan untuk mencatatakan informasi jaringan adalah jejaring test-netwok Rinkeby yang berbasis Proof-of-Authority (PoA) (POA, 2014).

Terdapat dua jenis data yang dicatatkan oleh program ini ke jejaring blockchain: 1) data konfigurasi jaringan, dan 2) data statistik jaringan.

Data konfigurasi jaringan yang dikirim ke jejaring blockchain bertujuan untuk mencatat riwayat perubahan konfigurasi jaringan (flow-rules pada setiap perangkat jaringan) di setiap kantor cabang dan memberikan identitas penomoran khusus pada setiap flow-rules yang dipasang.

Data statistik jaringan berisi nomor identitas dari setiap flow-rules beserta data statistik dari paket jaringan yang dikenai oleh flow-rules tersebut. Data statistik paket terdiri dari: waktu pencatatan data, jumlah paket, dan ukuran paket dalam bytes.

Tabel 1 menampilkan contoh format data yang dikirim ke jejaring blockchain. Untuk menghemat biaya pengiriman transkasi, daat konfigurasi jaringan hanya akan dikirim apabila flow-rules yang bersangkutan merupakan flow-rules baru. Sedangkan untuk pengiriman normal hanya dikirim data statistik jaringan. Transaksi smart contract menggunakan enkoding Unicode yang mana 1 digit data ASCII memerlukan kapasitas 2 bytes. Pada penenlitian ini akan digunakan enkripsi jenis AES yang memerlukan tambahan kapasitas data sekitar 1,33 kali ukuran paket asli. Kapasitas yang diperlukan oleh setiap jenis transaksi dalam bytes dapat ditunjukkan oleh Table 1.

Tabel 1. Kapasitas total setiap jenis transkasi dalam bytes

\begin{tabular}{cccc}
\hline $\begin{array}{c}\text { Jenis } \\
\text { informasi }\end{array}$ & $\begin{array}{c}\text { Flow-rules id } \\
\text { (digit) }\end{array}$ & $\begin{array}{c}\text { Data } \\
\text { (digit) }\end{array}$ & $\begin{array}{c}\text { Total data } \\
\left(\mathbf{F}_{\mathbf{i}}\right) \\
(\mathbf{b y t e s})\end{array}$ \\
\hline $\begin{array}{c}\text { Statistik } \\
\text { Konfigurasi }\end{array}$ & 4 & 24 & 75 \\
& 4 & 300 & 809
\end{tabular}

Pada penelitian ini akan diamati dua jenis skema transaksi yaitu transaksi smart contract $\left(\mathrm{T}_{\mathrm{SC}}\right)$, dan transaksi zero-payment $\left(\mathrm{T}_{\mathrm{ZP}}\right)$. Pemilihan ini berdasarkan pertimbangan nilai ekonomis dan keaman dari kedua jenis transaksi tersebut.

Dari segi integritas data, kedua jenis transaksi sama-sama mampu menjaga keamanan data. Hanya saja dari segi availability, transaksi berbasis smart contract lebih bagus dari pada transaksi jenis zeropayments. Pada transaksi smart contract, hanya pemilik smart contract yang dapat mencatatakan transkasi. Sedangkan pada transaksi zero-payment semua pemilik akun/alamat di jejaring Ethereum dapat mengirimkan transaksi ke alamat penerima. Pengelola pusat harus melakukan pemilahan transaksi berdasarkan alamat blockchain dari setiap perangkat switch yang diawasi.

Secara ringkas, diagram transaksi berbasis smart contract ditampilkan oleh Gambar 3.

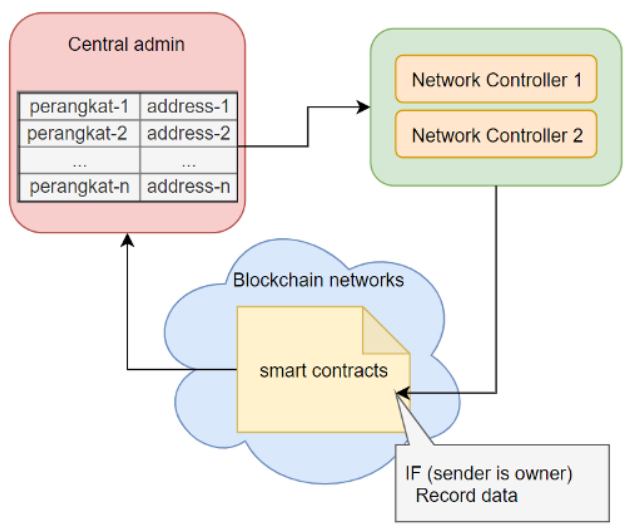

Gambar 3. Diagram pencatatan informasi jaringan berbasis transaksi smart contract 
Pada pengiriman berbasis smart contract, setiap perangkat jaringan memiliki satu buah alamat contract. Pengelola pusat menentukan alamat contract untuk setiap perangkat switch dan mengatur program controller yang mengendalikan perangkat switch sebagai pemilik sah dari dari contract tersebut. Dengan demikian, controller dapat menuliskan data konfigurasi dan statistik perangkat tersebut ke masing-masing smart contract dari setiap perangkat switch karena memiliki signature yang sah. Di sisi lain, pengelola pusat dapat menganalisa informasi jaringan dengan merujuk pada data yang tersimpan pada smart contract tersebut.

Pada pengiriman berbasis transaksi zeropayment, program controller mengirimkan informasi jaringan menggunakan sebuah transaksi bernilai nol (0) ke alamat pengelola pusat (Gambar 4). Pertamatama, pengelola pusat menginformasikan program controller mengenai alamat/akun blockchain dari setiap perangkat switch yang dikendalikan. Program controller menggunakan akun blockchain tersebut untuk mengirimkan informasi jaringan dari setiap perangkat switch. Data konfigurasi dan statistik jaringan disimpan kedalam input data dari transaksi zero-payment. Pengelola pusat dapat menganalisa informasi jaringan dengan mengunduh semua transaksi yang ditujukan ke alamatnya. Data dari setiap perangkat dapat dibedakan berdasarkan pada alamat pengirim transaksi.

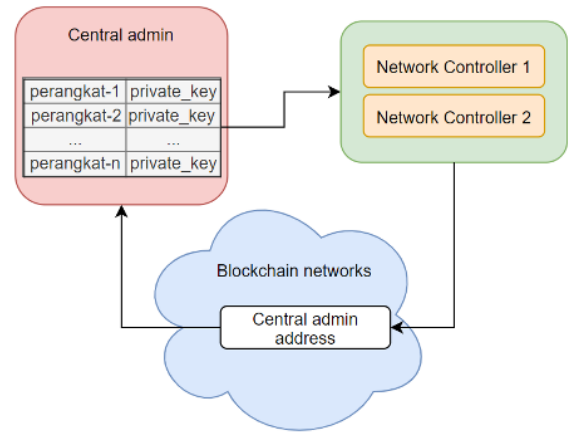

Gambar 4. Diagram pencatatan informasi jaringan berbasis transaksi zero-payment.

\subsection{Aplikasi pengawasan pusat}

Aplikasi pengawasan pusat bertugas untuk merekap dan menganalisa perubahan konfigurasi dan statistik dari setiap perangkat dari seluruh jaringan remote atau kantor cabang. Pertama-tama, aplikasi harus mengekstrak seluruh transaksi smart contract $\left(\mathrm{T}_{\mathrm{SC}}\right)$ atau transaksi zero-payment $\left(\mathrm{T}_{\mathrm{ZP}}\right)$ yang ditujukan kepadanya. Pengelola pusat dapat langsung mengekstrak data tersebut apabila pengelola pusat juga menjalankan sebuah node blockchain. Apabila tidak berperan sebagai node blockchain, maka pengelola pusat harus terlebih dahulu mengunduh daftar transaksi tersebut dari penyedia yang terpecaya seperti "etherscan.io" dan "infura.io". Karena informasi yang dikirim terenkripsi, maka aplikasi pengawasan pusat harus mendekripsi data laporan.

Terdapat dua aspek yang dianalisa oleh aplikasi pengawasan pusat, yaitu: 1) kesesuaian flow-rule di setiap perangkat jaringan dengan flow-rule yang ditetapkan, dan 2) anomali nilai pencacah dari paket jaringan yang dikenai oleh flow-rules tersebut. Dengan menganalisa kedua variabel tersebut, pengelola jaringan dapat memastikan bahwa perangkat jaringan di berbagai lokasi dapat berjalan sesuai dengan yang diharapkan dan tidak ada penyerang yang masuk ke jaringan.

Pengujian pada penelitian ini dilakukan pada dua kasus:

1. Deteksi akses ilegal ke jaringan tanpa izin,

2. Deteksi penyerangan ke perangkat switch.

Pada kasus pertama, pengelola pusat menerapkan konsep honey trap dengan mengizinkan akses masuk berdasarkan identifikasi alamat mesin perangkat (MAC address). Di sisi lain, pengelola pusat mewajibkan pegawai untuk mendaftarkan MAC address dari perangkat yang mereka gunakan. Dengan membandingkan data MAC address yang didaftarkan dengan data MAC address yang diproses oleh setiap perangkat switch, pengelola pusat dapat mendeteksi adanya upaya penyusupan oleh penyerang.

Dengan skema honey-trap, pihak penyerang merasa bahwa jaringan tidak diproteksi karena mereka dapat melakukan perintah ping ke perangkat lain di jaringan. Hanya saja, peyerang tidak dapat mengakses jaringan perusahaan lebih lanjut karena penggunaan firewall di setiap kantor cabang. Gambar 5 menunjukkan antarmuka pada progeram pengawasan pusat. Melalui program tersebut, pengelola pusat dapat mengetahui jumlah perangkat yang bersifat jahat/malicious, yaitu perangkat yang belum terdaftarkan tetapi sedang mengakses jaringan perusahaan.

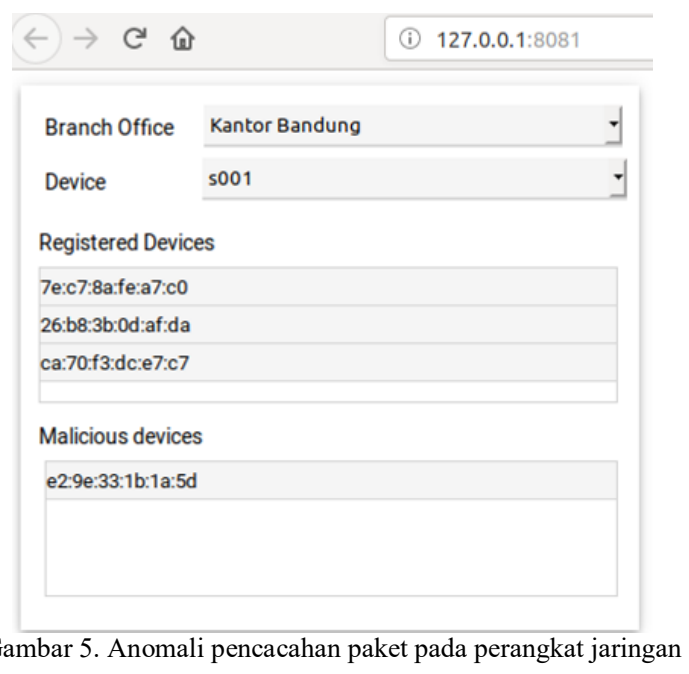

Sebagai langkah penanganan, program controller dapat memasang kembali flow-rules 
tersebut. Sebagai akibatnya, data pencacahan paket untuk flow-rules tersebut kembali bermula dari nol.

Pada kasus kedua, pengelola pusat dapat mengetahui kejadian penyerangan berdasarkan anomali data pencacahan paket (Gambar 6). Pengelola pusat dapat turun tangan dengan cepat untuk mengatasi insiden penyerangan tersebut. Lokasi masuk dari penyerang juga dapat diketahui karena sistem pelaporan statistik jaringan dilakukan per-perangkat jaringan. Pada pengujian ini penyerang masuk ke jaringan melalui switch berinisial s001.

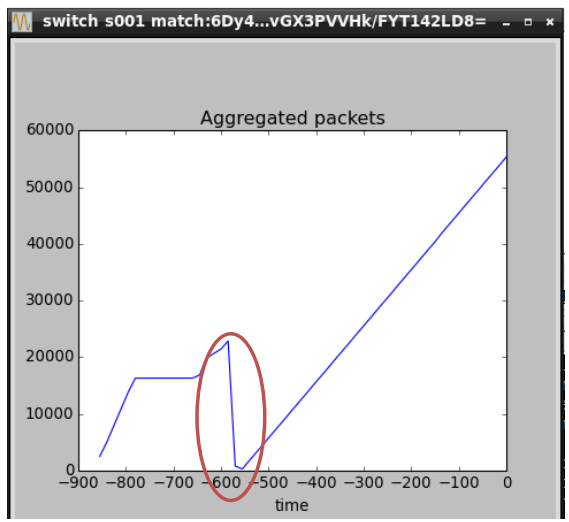

Gambar 6. Anomali pencacahan paket pada perangkat jaringan

\section{SKALABILITAS SISTEM PENCATATAN}

Skalabilitas sistem diukur berdasarkan biaya pengiriman transaksi pencatatan data. Berdasarkan persamaan 3 , biaya transaksi $\left(\mathrm{U}_{\text {cost }}\right)$ ditentukan oleh besarnya ukuran transaksi yang dikirim $\left(\mathrm{T}_{\text {size }}\right)$ dengan cara menyesuaikan nilai gas limit dari transaksi. Dengan menggunakan nilai gas limit yang cukup, maka kemungkinan besar transaksi yang dikirim dapat tercatatkan ke jejaring blockchain. Nilai minimum gas limit yang diperlukan dapat dihitung dengan mengkalikan besar ukuran input data transaksi $\left(\mathrm{T}_{\text {size }}\right)$ dengan nilai gas limit per byte (GLPB).

Gambar 7 menunjukkan hasil percobaan pencatatan transaksi ke jejaring blockchain dengan ukuran input data yang bervariasi. Pengujian dilakukan pada dua jenis skema pengiriman: transaksi berbasis smart contarct $\left(\mathrm{T}_{\mathrm{SC}}\right)$ dan zeropayment $\left(\mathrm{T}_{\mathrm{ZP}}\right)$. Nilai gas limit minimal untuk kedua skema pengiriman tersebut dapat dituliskan sebagai sebuah fungsi terhadap input data $\left(\mathrm{T}_{\text {size }}\right)$, sebagaimana ditunjukkan oleh persamaan 5 dan 6 . Satuan $\mathrm{T}_{\text {size }}$ adalah byte.

$$
\begin{aligned}
& G L_{S C}=600,2 T_{\text {size }}+42481 \\
& G L_{z P}=34 T_{\text {size }}+21000
\end{aligned}
$$

Hasil pengujian menunjukkan bahwa skema zero-payment memiliki biaya yang lebih rendah daripada skema smart contract untuk kedua kasus tersebut. Hal ini dikarenakan pada transaksi smart contract, node-node pada jejaring blockchain harus menjalankan fungsi smart contract seperti mengecek alamat pengirim, menaikkan nilai pencacahan data, serta menyimpan data yang dikirim. Sedangkan untuk pengiriman berbasis zero-payment, node-node blockchain hanya sekedar mencatat transaksi tanpa melakukan eksekusi suatu fungsi. Sebagaimana telah dijelaskan pada sub bab 3.2, meskipun transaksi smart contract lebih mahal, akan tetapi transaksi smart contract memiliki hasil pencatatan yang lebih rapi dan aman dari serangan transaksi spam.

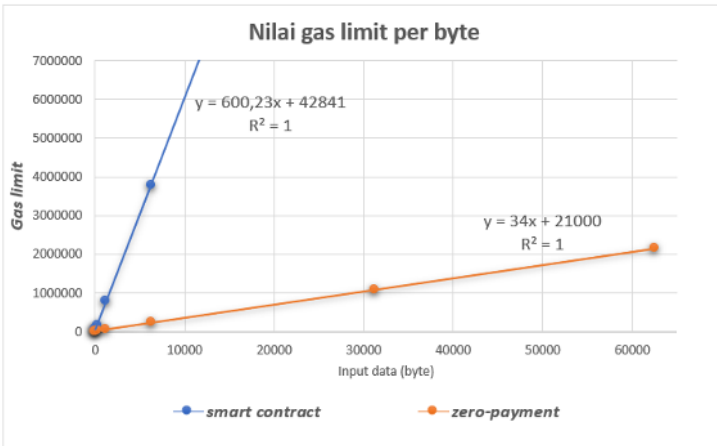

Gambar 7. Nilai gas limit sebagai fungsi besaran input data transaksi pada jaringan blockchain Ethereum-Rinkeby

Jejaring blockchain membatasi ukuran transaksi untuk mencegah serangan denial-ofservices (DoS) (Bab 2). Jejaring Ethereum-Rinkeby memiliki batas gas limit sebesar 7 juta dan batas kapasitas input data transaksi sebesar 65 Kbyte. Berdasarkan persamaan 5, transaksi smart contract akan terlebih dahulu mengalami keterbatasan biaya daripada keterbatasan kapasitas. Ukuran input data maksimal yang didukung adalah sekitar 11500 bytes. Berdasarkan persamaan 6 , transaksi zero-payment akan terlebih dahulu memiliki keterbatasan kapasitas (65 Kbytes).

Tabel 2 menunjukkan nilai gas limit yang dibutuhkan untuk mengirimkan informasi jaringan pada perangkat dengan jumlah flow-rules rendah (10 flow-rules) dan tinggi (100 flow-rules). Nilai $\mathrm{T}_{\text {size }}$ dalam bytes adalah $\mathrm{N}_{\mathrm{R}} \times \mathrm{F}_{\mathrm{i}}$.

Tabel 2. Perbandingan gas limit pada transaksi jenis smart

\begin{tabular}{ccrrr}
\multicolumn{5}{c}{ contract dan zero-payment } \\
\hline$\left(\mathbf{N}_{\mathbf{R}}\right)$ & Jenis & $\begin{array}{c}\boldsymbol{T}_{\text {size }} \\
\text { (bytes) }\end{array}$ & $\begin{array}{c}\text { Gas limit } \\
\left(\boldsymbol{T}_{\boldsymbol{S C}}\right)\end{array}$ & \multicolumn{1}{c}{ Gas limit } \\
$\left(\boldsymbol{T}_{\boldsymbol{Z} P}\right)$
\end{tabular}

Berdasarkan Tabel 2, pengiriman data konfigurasi (Configs) pada jaringan dengan flowrules tinggi (100) tidak dapat dilakukan dengan satu buah transaksi karena melebihi kapasitas input data maksimum 65 Kbyte. Namun demikian, karena data konfigurasi hanya perlu dikirim ketika terjadi 
perubahan, hal ini tidak terlalu berpengaruh pada skalabilitas sistem. Karena perubahan konfigurasi jaringan tidak terlalu sering terjadi, maka potensi terjadinya race-condition pada pengiriman transaksi dapat diminimalkan.

Hal yang paling mempengaruhi skalabilitas sistem adalah pada pengiriman statistik jaringan (Stats) karena harus dicatat secara periodik. Ancaman skalabilitas pada pengiriman data statistik berasal dari biaya pengiriman transaksi yang tinggi. Sedangkan ancaman skalabilitas dari race condition sangat minimal karena data statistik dapat dikirimkan dalam sekali transaksi tanpa melebihi ambang batas ukuran input data ataupun gas limit.

Tabel 3. Perkiraan biaya pencatatan statistik jaringan per-hari

\begin{tabular}{ccccc}
\multicolumn{5}{c}{ untuk $\mathrm{N}_{\mathrm{R}}=100}$. \\
\hline Jenis & $\mathbf{U}_{\text {cost }} /$ Trx & $\mathbf{U}_{\text {cost }} /$ day & $\mathbf{U}_{\text {cost }} /$ day & $\mathbf{U}_{\text {cost }} /$ day \\
transaksi & (Ether) & @15 dtk & @1 mnt & @10 mnt \\
\hline $\mathrm{T}_{\mathrm{SC}}$ & 0,004544 & 392,6016 & 6,54336 & 0,654336 \\
$\mathrm{~T}_{\mathrm{ZP}}$ & 0,000276 & 23,8464 & 0,39744 & 0,039744
\end{tabular}

Tabel 3 menunjukkan perkiraan biaya pengiriman transaksi untuk pencatatan informasi jaringan ke jejaring blockchain. Nilai gas-price pertranskasi yang digunakan adalah 1 Gwei. Perkiraan dilakukan pada tiga jenis waktu pensampelan yang berbeda (15 detik, 1 menit, dan 10 menit). Kasus yang diamati adalah perangkat dengan jumlah flowrules tinggi (100 buah).

Berdasarkan Tabel 3, transaksi zero-payment hanya memerlukan biaya pengiriman sekitar $6 \%$ dari biaya transaksi smart contract. Dengan demikian, transaksi berbasis zero-payment memiliki skalabilitas biaya pengiriman transaksi yang lebih bagus. Pada transaksi zero-payment, biaya per-bulan per-perangkat yang diperlukan adalah 30 x 0,039744 $=1,19232$ ethers

Meskipun biaya bulanan per-perangkat hanya berkisar 1,19232 Ethers, skema pencatatan tersebut tidak sesusai untuk diimplementasikan pada jejaring Ethereum main-network yang berbasis Proof-ofWork (PoW) (Buterin, 2014) karena biaya riil yang diperlukan sangat tinggi. Pada saat penelitian ini dilakukan, harga 1 Ether adalah sekitar \$ 200. Dengan demikian, biaya bulanan yang diperlukan untuk mencatatkan informasi per-perangkat jaringan adalah sekitar $\$ 238,464$. Apabila perusahaan memiliki N-buah perangkat jaringan, maka total biaya yang diperlukan menjadi $\mathrm{N}$ kali lipat.

\section{DISKUSI}

Alternatif skema pengiriman data yang lebih ekonomis adalah dengan menggunakan jejaring penyimpanan file terdistribusi seperti Interplanetary File Sytem (IPFS). Penggunaan jejaring IPFS untuk meminimalisir pencatatan data telah diimplementasikan pada beberapa penelitian terdahulu (Gries, S. dkk, 2018) (de Tazoult dkk, 2019). Data yang akan dilaporkan disimpan di jejaring IPFS sedangkan nilai hash dari data tersebut dicatatkan di jejaring blockchain. Perubahan data pelaporan dapat diketahui dengan membandingkan nilai hash dari data yang tersimpan di jejaring IPFS dengan nilai hash yang tercatat di jejaring blockchain. Biaya pencatatan dapat diminimalisir karena hanya nilai hash dari data pelaporan yang perlu dicatatkan ke jejaring blockchain.

Penelitian ini tidak menggunakan penyimpanan berbasis jejaring IPFS karena sistem penyimpanan berbasis IPFS tidak dapat sepenuhnya menjamin ketersediaan (availability) data. Data yang tersimpan di jejaring IPFS tidak otomatis terreplikasi di berbagai tempat yang berbeda. Pengguna harus memastikan sendiri proses replikasi data ke berbagai server yang berbeda lokasi agar terjaga ketersediaan salinan datanya. Pemilihan node-node yang bertugas untuk menduplikasi data pelaporan perlu ditentukan dengan seksama dan merupakan topik penelitian tersendiri.

Penelitian ini menggunakan jejaring Ethereum Rinkeby yang berbasis Proof-of-Authotrity (PoA). Kelemahan dari skema PoA adalah tingkat ketersediaan data (availability) lebih rendah dibandingkan dengan skema PoW. Data pelaporan hanya tersimpan pada beberapa nodes authority. Untuk meningkatkan ketersedian data, maka jumlah node authority perlu ditambah.

Pengelola pusat dapat berpatisipasi dengan berperan sebagai salah satu node authority, sehingga memiliki salinan data pelaporan secara lokal. Apabila penyerang berhasil memutus koneksi internet di kantor pusat, pengelola pusat masih memiliki salinan rekaman data pelaporan. Rekaman data tersebut dapat digunakan untuk melacak skema penyerangan yang telah dilakukan, sehingga perbaikan sistem jaringan dapat dilakukan secara lebih cepat dan terarah.

\section{KESIMPULAN}

Pada penelitian ini dikembangkan purwarupa pengawasan informasi jaringan secara terpusat menggunakan jejaring Ethereum-Rinkeby. Sistem jaringan yang diawasi adalah jaringan berbasis SDN. Skema transaksi untuk pencatatan informasi jaringan terdiri dari dua jenis, yaitu transaksi berbasis smart contract, dan transaksi berbasis zero-payment. Hasil pengujian menunjukkan bahwa, transaksi zeropayment lebih efisien dengan hanya membutuhkan sekitar $6 \%$ dari biaya transaksi smart contract. Metode pencatatan yang diajukan pada penelitian ini lebih sesuai untuk diimplementasikan pada jejaring Ethereum Proof-of-Authority dibandingkan Proofof-Work karena biaya pencatatan bulanan perperangkat yang tinggi, sekitar 1,12 Ether.

\section{DAFTAR PUSTAKA}

BUTERIN, V. 2014. A next-generation smart contract and decentralized application platform. white paper, 3, 37 . 
DE TAZOULT, C. T., CHIKY, R., \& FOLTESCU, V. 2019. A Distributed Pollution Monitoring System: The Application of Blockchain to Air Quality Monitoring. In International Conference on Computational Collective Intelligence (pp. 688-697). Springer, Cham.

EL HOUDA, Z. A., HAFID, A. S., \& KHOUKHI, L. 2019. Cochain-SC: An intra-and interdomain Ddos mitigation scheme based on blockchain using SDN and smart contract. IEEE Access, 7, 98893-98907.

Ethers.js. 2016. What is ethers.js. [online] Tersedia di <https://github.com/ethers-io/ethers.js/> [Diakses 2 Oktober 2019]

FIESSLER, A., LORENZ, C., HAGER, S., \& SCHEUERMANN, B. . . 2018 FireFlow-High Performance Hybrid SDNFirewalls with OpenFlow. In 2018 IEEE 43rd Conference on Local Computer Networks (LCN) (pp. 267-270). IEEE.

GERMANN, B., SCHMIDT, M., STOCKMAYER, A., \& Menth, M. 2018. OFFWall: A Static OpenFlow-Based Firewall Bypass. In 11. DFN-Forum Kommunikationstechnologien. Gesellschaft für Informatik $\mathrm{eV}$.

GRIES, S., MEYER, O., WESSLING, F., HESENIUS, M., \& GRUHN, V. 2018. Using Blockchain Technology to Ensure Trustful Information Flow Monitoring in CPS. In IEEE International Conference on Software Architecture Companion (ICSAC) (pp. 35-38).

HELEBRANDT, P., BELLUS, M., RIES, M., KOTULIAK, I., \& KHILENKO, V. 2018. Blockchain Adoption for Monitoring and Management of Enterprise Networks. In IEEE 9th Annual Information Technology, Electronics and Mobile Communication Conference (IEMCON) (pp. 1221-1225).

KAMBOJ, P., \& PAL, S. 2019. QoS in software defined IoT network using blockchain based smart contract. In Proceedings of the 17th Conference on Embedded Networked Sensor Systems (pp. 430-431). ACM.

KAUR, K., SINGH, J., \& GHUMMAN, N. S. 2014 Mininet as software defined networking testing platform. In International Conference on Communication, Computing \& Systems (ICCCS) (pp. 139-42).

KOŠŤÁL, K., HELEBRANDT, P., BELLUŠ, M., RIES, M., \& KOTULIAK, I. 2019. Management and Monitoring of IoT Devices Using Blockchain. Sensors, 19(4), 856.

MENDEZ MENA, D. M., \& YANG, B. (2018, September). Blockchain-Based Whitelisting for Consumer IoT Devices and Home
Networks. In Proceedings of the 19th Annual SIG Conference on Information Technology Education (pp. 7-12). International World Wide Web Conferences Steering Committee.

MCKEOWN, N., ANDERSON, T., BALAKRISHNAN, H., PARULKAR, G., PETERSON, L., REXFORD, J., ... \& TURNER, J. 2008. OpenFlow: enabling innovation in campus networks. ACM SIGCOMM Computer Communication Review, 38(2), 69-74.

NIYA, S. R., JHA, S. S., BOCEK, T., \& STILLER, B. 2018. Design and implementation of an automated and decentralized pollution monitoring system with blockchains, smart contracts, and LoRaWAN. In NOMS 20182018 IEEE/IFIP Network Operations and Management Symposium (pp. 1-4).

PATIL, S., \& SUBHEDAR, M. S. 2019. Optimizing MPLS Tunnel Creation Performance by Using SDN. In Soft Computing and Signal Processing (pp. 527-536). Springer, Singapore.

PFAFF, B., PETTIT, J., KOPONEN, T., JACKSON, E., ZHOU, A., RAJAHALME, J., ... \& AMIDON, K. 2015. The design and implementation of open vswitch. In 12th \{USENIX\} Symposium on Networked Systems Design and Implementation (\{NSDI\} 15) (pp. 117-130).

PHATAK, A., KADIKAR, R., VIJAYAN, K., \& AMUTHA, B. ,2018. Performance Analysis of Firewall Based on SDN and OpenFlow. In 2018 International Conference on Communication and Signal Processing (ICCSP) (pp. 0611-0615). IEEE.

POA. 2014, Welcome to POA. [online] Tersedia di $<$ https://www.poa.network/ PoA $>$ [Diakses 2 Oktober 2019]

Ryu SDN Framework. 2011. [online] Tersedia di $<$ https://osrg.github.io/ryu/> [Diakses 1 Oktober 2019]

SUBRATIE, K. \& FIGUEIREDO, R. (2018, October). Towards Island Networks: SDNEnabled Virtual Private Networks with Peer-to-Peer Overlay Links for Edge Computing. In International Conference on Internet and Distributed Computing Systems (pp. 122-133). Springer, Cham.

VAN DER POL, R., GIJSEN, B., ZURANIEWSKI, P., ROMÃO, D. F. C., \& KAAT, M. 2016. Assessment of SDN technology for an easy-to-use VPN service. Future Generation Computer Systems, 56, 295302. 
Halaman ini sengaja dikosongkan 